Article

\title{
Novel Barbiturate-Nitrate Compounds Inhibit the Upregulation of Matrix Metalloproteinase-9 Gene Expression in Intestinal Inflammation through a cGMP-Mediated Pathway
}

\author{
Shane O’Sullivan ${ }^{\circledR}$, Jun Wang, Marek W. Radomski, John F. Gilmer and Carlos Medina * \\ School of Pharmacy and Pharmaceutical Sciences, Trinity Biomedical Sciences Institute, Trinity College Dublin, \\ 2 Dublin, Ireland; osullish@tcd.ie (S.O.); wangju@tcd.ie (J.W.); marek.radomski@usask.ca (M.W.R.); \\ gilmerjf@tcd.ie (J.F.G.) \\ * Correspondence: carlos.medina@tcd.ie
}

Received: 29 April 2020; Accepted: 22 May 2020; Published: 25 May 2020

check for updates

\begin{abstract}
Matrix metalloproteinase- 9 is upregulated in inflammatory bowel disease. Barbiturate nitrate hybrid compounds have been designed to inhibit MMP secretion and enzyme activity. In this study, we investigated the mechanism of action of barbiturate-nitrate hybrid compounds and their component parts using models of intestinal inflammation in vitro. Cytokine-stimulated Caco-2 cells were used in all in vitro experiments. The NO donors SNAP and DETA-NONOate were used to study the effect of NO on MMP-9 mRNA. Mechanistic elucidation was carried out using the soluble guanylate cyclase (sGC) inhibitor, ODQ, and the cGMP analogue, 8-Bromo-cGMP. Further experiments were carried out to elucidate the role of NF- $\mathrm{KB}$. NO donors exerted an inhibitory effect on MMP-9 mRNA in cytokine-stimulated cells. While the non-nitrate barbiturates had a limited effect on MMP-9 expression, the hybrid compounds inhibited MMP-9 expression through its NO-mimetic properties. No effect could be observed on mRNA for MMP-1 or MMP-2. The SGC inhibitior, ODQ, abolished the nitrate-barbiturate inhibition of MMP-9 gene expression, an effect which was reversed by 8-Br-cGMP. This study shows that the barbiturate scaffold is suitable for hybrid design as an MMP-9 inhibitor in cytokine-stimulated Caco- 2 cells. The inhibition of MMP-9 levels was largely mediated through a reduction in its mRNA by a sGC/cGMP pathway mediated mechanism.
\end{abstract}

Keywords: inflammatory bowel disease; inflammation; NO; MMP-9; cGMP; Caco-2

\section{Introduction}

The matrix metalloproteinases are a group of endopeptidases capable of digesting the extracellular matrix (ECM), basement membrane as well as having an immunomodulatory role related to activation of other proteases and inflammatory mediators [1-3]. Inflammatory bowel disease (IBD), which encompasses ulcerative colitis (UC) and Crohn's disease (CD), is a chronic, relapsing condition involving inflammation of the gut leading to abdominal pain, diarrhoea, rectal bleeding and fever. MMP-9 is known to be up-regulated in IBD [4-7] and is associated with disruption of the epithelial barrier and activation of pro-inflammatory mediators [8-11]. Inhibition of this enzyme may therefore aid in reducing the severity of the disease. The development of clinically useful synthetic inhibitors has, to date, been disappointing, mainly due to dose-limiting side-effects but it is also true that the efficacy evident in animal models has not translated [12,13]. This has led to a revaluation of the precise role of specific MMPs in a given pathological setting and to investigate new strategies for modulating dysregulated MMP activity in disease tissue. Certain appropriately substituted barbiturates have been shown to possess MMP inhibitory characteristics [14,15] while being without 
sedative actions [16]. The barbiturates have, in general, better pharmacokinetic properties than other MMP inhibitory compounds such as, for example, the hydroxamates. Our group reported a series of barbiturate-nitrate hybrid compounds that are potent inhibitors of MMP-2 and MMP-9 at the enzyme level [17]. Incorporation of a nitrate group as a nitric oxide (NO) donor or mimetic functionality was intended to confer on the compounds an ability to modulate the enzyme levels of inducible MMP in order to complement the purely enzyme inhibitory actions of the barbiturate zinc binding group. Interactions between NO and MMP-9, which have been recently reviewed, are complex and difficult to predict [18]. In our previous work we showed that the hybrid compounds were able to reduce MMP- 9 activity in cell supernatants as measured by gelatin zymography, a property that was not shared by barbiturate inhibitors not bearing a nitrate group. Furthermore, the hybrid compounds were significantly more efficacious than the non-nitrate counterparts in a model of MMP-9 dependent cancer cell invasion [17]. Consistent with this, we subsequently found that one of the hybrid compounds was more effective in an animal model of IBD than the MMP inhibitor from which it was derived or its incorporated nitrate component [19]. The objective of the present study was to determine the mechanism by which the hybrid compounds influence MMP levels, to investigate the role of NO in this and to assess the selectivity for MMP-9 over other MMP enzymes. We found that the inhibition of MMP-9 mRNA was largely mediated through a reduction in its mRNA by a sGC/cGMP-mediated pathway.

\section{Material and Methods}

All chemicals and biological materials were supplied by Sigma Aldrich ${ }^{\circledR}$ (Dublin, Ireland) unless otherwise stated.

In this study, we used a group of barbiturate-nitrate hybrid compounds and their component parts that were previously synthesized in our lab [17].

\subsection{Cell Culture}

Caco-2 cells were supplied by the European Collection of Cell Cultures (ECACC, Salisbury, UK). Cells were cultured in minimum essential media (MEM) containing $20 \%$ fetal bovine serum (FBS), $1 \%$ sodium pyruvate, sodium bicarbonate $2.2 \mathrm{~g} / \mathrm{L}$, gentamicin $5 \mathrm{mg} / \mathrm{L}$, streptomycin $10 \mathrm{mg} / \mathrm{L}$, penicillin $\mathrm{G} 6 \mathrm{mg} / \mathrm{L}$. Cells were maintained in a $37^{\circ} \mathrm{C}, 5 \% \mathrm{CO}_{2}$ humidified incubator until approximately $75 \%$ confluent. All the following in vitro experiments were carried out in FBS-free media. Cells were incubated with 3 series of test compounds at $10 \mu \mathrm{M}$ for $30 \mathrm{~min}$. The dose of $10 \mu \mathrm{M}$ was chosen in accordance with our previous study were toxicological studies were carried out [17]. Cytokines TNF- $\alpha$ and IL-1 $\beta$ $10 \mathrm{ng} / \mathrm{mL}$ were then added and the cells were incubated for $24 \mathrm{~h}$. For NO-donor experiments, solutions of SNAP or DETA-NONOate were prepared daily when needed and incubated (in the concentration range 10 to $500 \mu \mathrm{M}$ ). For co-incubation experiments with ODQ, this was added with the nitrate-barbiturate hybrids to give a concentration in the serum-free media of $10 \mu \mathrm{M}$ as with the compounds. In experiments where 8-Br-cGMP was used, this was added with the ODQ and compounds to give a final concentration of $10 \mu \mathrm{M}$ in the serum-free media.

\subsection{Gelatin Zymography}

The conditioned media from cell experiments was removed, centrifuged at 13,000 rpm for $5 \mathrm{~min}$ to remove dead cells or floating debris and the resulting cell-free supernatants were stored at $-80^{\circ} \mathrm{C}$ until assayed for MMP-2 and MMP-9 using gelatin zymography. Briefly, samples were normalized with respect to protein content using a Bradford assay. The enzymatic activities of MMP-2 and MMP-9 were assayed by gelatin zymography in serum-free media. The samples were electrophoresed on an SDS-PAGE containing $2 \%$ gelatin. The gels were washed with $2.5 \%$ Triton $X$ three times for $20 \mathrm{~min}$ cycles. The gels were then washed twice and finally incubated with zymography buffer $(0.15 \mathrm{M} \mathrm{NaCl}$, $5 \mathrm{mM} \mathrm{CaCl} 2,0.05 \% \mathrm{NaN}_{3}$, and $50 \mathrm{mM}$ Tris- $\mathrm{HCl}$ buffer, $\mathrm{pH} 7.5$ ) at $37^{\circ} \mathrm{C}$ for $48 \mathrm{~h}$. After incubation, the gels were stained with $0.025 \%$ Coomassie Brilliant Blue G250 in 25\% MeOH, 10\% acetic acid, 
and $\mathrm{H}_{2} \mathrm{O}$ and destained with acetic acid $8 \%$, methanol $4 \%$, and $\mathrm{H}_{2} \mathrm{O}$. The gelatinolytic activity was detected as a band of gelatin digestion and was quantified by densitometry using gel documentation system r (Bio-Rad, Dublin, Ireland, Universalhood II and Quantity One 4.6 software) and expressed as a percentage of the positive control.

\subsection{Quantitative PCR}

Quantitative PCR (qPCR) was used to study the effect of the different compounds on expression of MMP-1, MMP-2 and MMP-9 and NF- $\kappa$ B in cytokine-stimulated cells. Briefly, the RNA was isolated using RNAqueous-4PCR ${ }^{\circledR}$ kit from Ambion (Applied Biosystems, Waltham, MA, USA) according to the manufacturer's protocol. The concentration and purity of the RNA yielded was measured using the NanoDrop ND-1000. RNA samples were converted to single-stranded cDNA using a High Capacity cDNA Reverse Transcription kit (Applied Biosystems, Waltham, MA, USA). As target probes, TaqMan MGB human MMP-9 (Hs 00234579_m1), NOS (Hs 01075521_m1), NFKB1 (Hs 00949904_m1), RelA (Hs 01042014_m1) and IKBKG (Hs 01006763_m1) were used. Endogenous 18s rRNA was used as a control to normalize gene expression data, and an RQ value $\left(2^{-\Delta \Delta C t}\right.$, where $\mathrm{Ct}$ is the threshold cycle) was calculated for each sample. RQ values are presented as fold change in gene expression relative to the stimulated group, which was normalized to 1 .

\subsection{Nitrate and Nitrite Quantification-Modified Griess Assay}

A spectrophotometric method was used to measure the nitrate and nitrite in conditioned media. Nitrate and nitrite standards were serially diluted to a range $1.6-200 \mu \mathrm{M}$ in $\mathrm{ddH}_{2} \mathrm{O}$ and $200 \mu \mathrm{L}$ of each concentration was added to 12 -well plates in duplicate. Nitrate was reduced to nitrite with the addition of $200 \mu \mathrm{L}$ saturated vanadium (III) solution $(400 \mathrm{mg} \mathrm{VCl}$ in $50 \mathrm{~mL} 1 \mathrm{M} \mathrm{HCl})$ and then staining of the nitrite was carried out with rapid addition of $100 \mu \mathrm{L}$ sulfanilamide $(2 \% w / v$ in $5 \% v / v \mathrm{HCl})$ and $100 \mu \mathrm{L}$ $\mathrm{N}-1$-(naphthyl) ethylenediamine (NEDD) $\left(0.1 \% w / v\right.$ in $\left.\mathrm{ddH}_{2} \mathrm{O}\right)$. The plate was incubated with rocking for $45 \mathrm{~min}$ and absorbance was read at $\lambda 540 \mathrm{~nm}$. Measurement of nitrite standards were carried out as above with $\mathrm{ddH}_{2} \mathrm{O}$ added instead of $\mathrm{VCL}_{3}$ solution and $\mathrm{ddH}_{2} \mathrm{O}$ was used as a blank for both sets of standards. Conditioned media samples were normalised for protein concentration, and $200 \mu \mathrm{L}$ loaded onto 12-well plates in duplicate for both methods described above used to measure the nitrite and nitrate levels. Addition of $\mathrm{VCl}_{3}$ to the conditioned media samples will give a measure of total $\mathrm{NO}_{2}^{-}$ and $\mathrm{NO}_{3}{ }^{-}$given $\mathrm{NO}_{\mathrm{x}}{ }^{-}$.

\subsection{NF- $\kappa B$ (p65) Binding Activity}

The binding activity of the p65 subunit was measured using an NF-kB (p65) Enzyme Linked Immunosorbent Assay (ELISA) kit (Cayman Chemicals, Dublin, Ireland). Nuclear extraction was first carried out from cultured and treated cells after $24 \mathrm{~h}$ using the nuclear extraction kit (Cayman Chemicals, Dublin, Ireland) according to the manufacturer's protocol. The biding of p65 in these nuclear extracts was then determined using the NF- $\mathrm{kB}$ (p65) transcription factor assay according to the manufacturer's instructions.

\subsection{Statistical Analysis}

Analysis of results was carried out using Graph Pad Prism ${ }^{\circledR} 5$ for Windows (San Diego, CA, USA, Graph Pad software). All results shown represent $n \geq 3$ and were analyzed using a one way ANOVA and Dunnett's or Tukey post-test where appropriate. Graphs are presented as the mean \pm the standard error of the mean (SEM) and statistical significance was judged as a $p$ value of $<0.05$. 


\section{Results}

\subsection{Barbiturate-Nitrate Hybrids Reduce MMP-9 Expression in Cytokine-Stimulated Caco-2 Cells}

We have previously demonstrated that the barbiturate-nitrate hybrids (series 1, Figure 1) can reduce supernatant MMP-9 activity as measured by gelatin zymography to a greater extent than the barbiturate-alcohols (series 2, Figure 1) [17]. Here we examine the effect of the hybrid compounds at the gene level and use the barbiturate-alcohols and nitrate side-chains (series 3, Figure 1) to measure the relative contributions of the component parts of the series of compounds.

Nitrate side-chain

Figure 1. Structures of compounds used. Column one shows the nitrate side-chains. Columns two and three show the barbiturate scaffold and the nitrate and alcohol side-chains, respectively.

The nitrate-barbiturates $(10 \mu \mathrm{M})$ caused a statistically significant reduction in MMP-9 mRNA in cytokine-stimulated Caco-2 cells after $24 \mathrm{~h}$ compared to the untreated, stimulated cells (Figure 2). Compounds 1c and 1a caused the greatest mean inhibition. The alcohol-barbiturates also inhibited the transcription of MMP-9 at $10 \mu \mathrm{M}$ but to a lesser extent. The nitrate side-chains did reduce MMP-9 expression when tested at $10 \mu \mathrm{M}$ (Figure 2), but this inhibition did not reach statistical significance except for compound 3f. The compounds in parallel experiments did not affect mRNA levels of MMP-1 or MMP-2, showing selectivity for inhibition of MMP-9. 


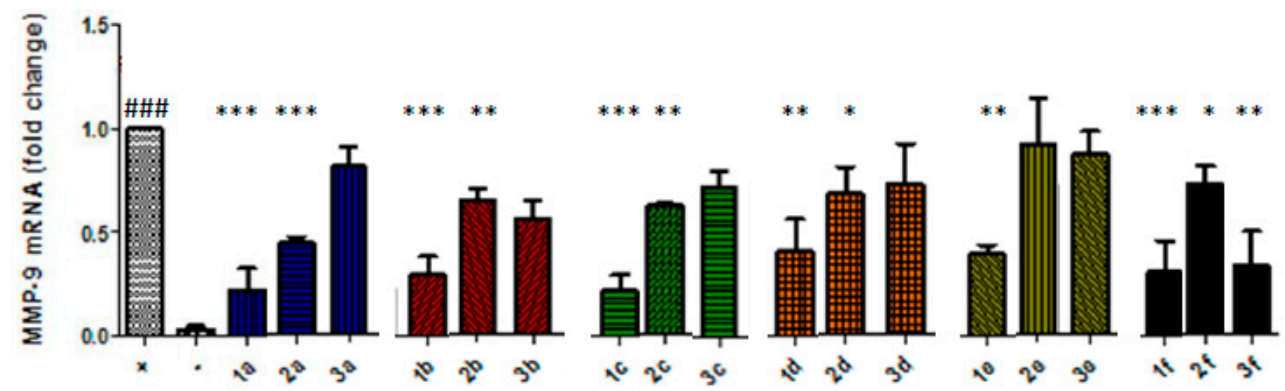

Figure 2. Barbiturate-nitrate hybrids (series 1) reduce MMP-9 mRNA to a greater extent than the barbiturate alcohols (series 2) or the nitrate side-chains (series 3). Caco-2 cells were incubated with series of the barbiturate-nitrate hybrids, barbiturate-alcohols or nitrate side-chains at $10 \mu \mathrm{M}$ for $30 \mathrm{~min}$ prior to addition of TNF- $\alpha$ and IL-1 $\beta(10 \mathrm{ng} / \mathrm{mL})$. \#\#\# $p<0.001 \mathrm{vs}$. unstimulated Caco- 2 cells (negative control); ${ }^{*} p<0.05$ vs. cytokine-stimulated Caco- 2 cells (positive control); ${ }^{* *} p<0.01$ vs. positive control; *** $p<0.001$ vs. positive control.

\subsection{Nitric Oxide Donors Reduce MMP-9 mRNA Levels in Cytokine-Stimulated Caco-2 Cells}

In order to establish whether the effects that the nitrate-barbiturates had on MMP-9 mRNA in cytokine-stimulated Caco-2 cells were NO-mediated, we tested the effects of two NO-donors at a range of concentrations for $24 \mathrm{~h}$. In this study we used the S-nitrosothiol, S-Nitroso- $\mathrm{N}$-acetylpenicillamine (SNAP), which has been previously shown to have a half-life in aqueous media of approximately $4 \mathrm{~h}$; the $\mathrm{NO}$ formation is high, where $100 \mu \mathrm{M}$ yields about $1.4 \mu \mathrm{M} \mathrm{NO} /$ minute at $37^{\circ} \mathrm{C}$, and it is linear over a wide concentration range. In addition, we measured the effects of the diazeniumdiolate compound DETA-NONOate, which decomposes spontaneously and has been demonstrated to have a half-life of $20 \mathrm{~h}$ at $\mathrm{pH} 7.4$ and $37^{\circ} \mathrm{C}[20]$.

We found that DETA-NONOate reduced MMP-9 expression with the highest concentration tested (Figure 3A). Figure 3B shows the release of NO species. As expected from a NONOate NO-donor, there was a linear relationship between the concentration used and the $\mathrm{NO}$ released with correlation analysis results for $\mathrm{NO}_{\mathbf{x}}{ }^{-}\left(p<0.0001, \mathrm{R}^{2}=0.9975\right), \mathrm{NO}_{2}{ }^{-}\left(p<0.0001, \mathrm{R}^{2}=0.9996\right)$ and $\mathrm{NO}_{3}{ }^{-}(p<0.0001$, $\mathrm{R}^{2}=0.9828$ ) being statistically significant. There was little to no difference in NO yielded from the lower concentrations of DETA-NONOate used, which may reflect the limited sensitivity of the Griess assay. At a concentration of $500 \mu \mathrm{M}$, DETA-NONOate yielded statistically significantly more of all $\mathrm{NO}_{\mathrm{x}}{ }^{-}$species than the positive control. The highest concentrations of nitrate and nitrite were produced from the highest concentration of DETA-NONOate, which also produced a significant inhibition of MMP-9 at the gene level.

We also found that the addition of SNAP caused a significant inhibition of MMP-9 at the gene level at all concentrations tested (Figure 4A). Figure 4B shows the release of NO species. Incubations with SNAP showed a linear correlation between the concentration used and the resultant nitrate and nitrite concentrations that were present in the conditioned media after $24 \mathrm{~h}$. The results of correlation analysis of SNAP concentration and $\mathrm{NO}_{\mathrm{x}}{ }^{-}\left(p<0.0001, \mathrm{r}^{2}=0.9964\right), \mathrm{NO}_{2}\left(p<0.0001, \mathrm{r}^{2}=0.9696\right)$ and $\mathrm{NO}_{3}{ }^{-}\left(p=0.0002, \mathrm{r}^{2}=0.9525\right)$ are unsurprising considering that SNAP is expected to spontaneously yield NO, which will be decomposed to nitrite and nitrate. At $500 \mu \mathrm{M} \mathrm{SNAP}$, the difference in nitrite concentrations reached statistical significance for all groups. Similar results were observed for nitrate and $\mathrm{NO}_{\mathrm{x}}{ }^{-}$concentrations, where $500 \mu \mathrm{M}$ SNAP resulted in statistically significant differences with all other groups, and $200 \mu \mathrm{M}$ was also statistically different from the controls and $10 \mu \mathrm{M}$ SNAP. There is no obvious correlation between these results and the effect on MMP-9 gene expression. 

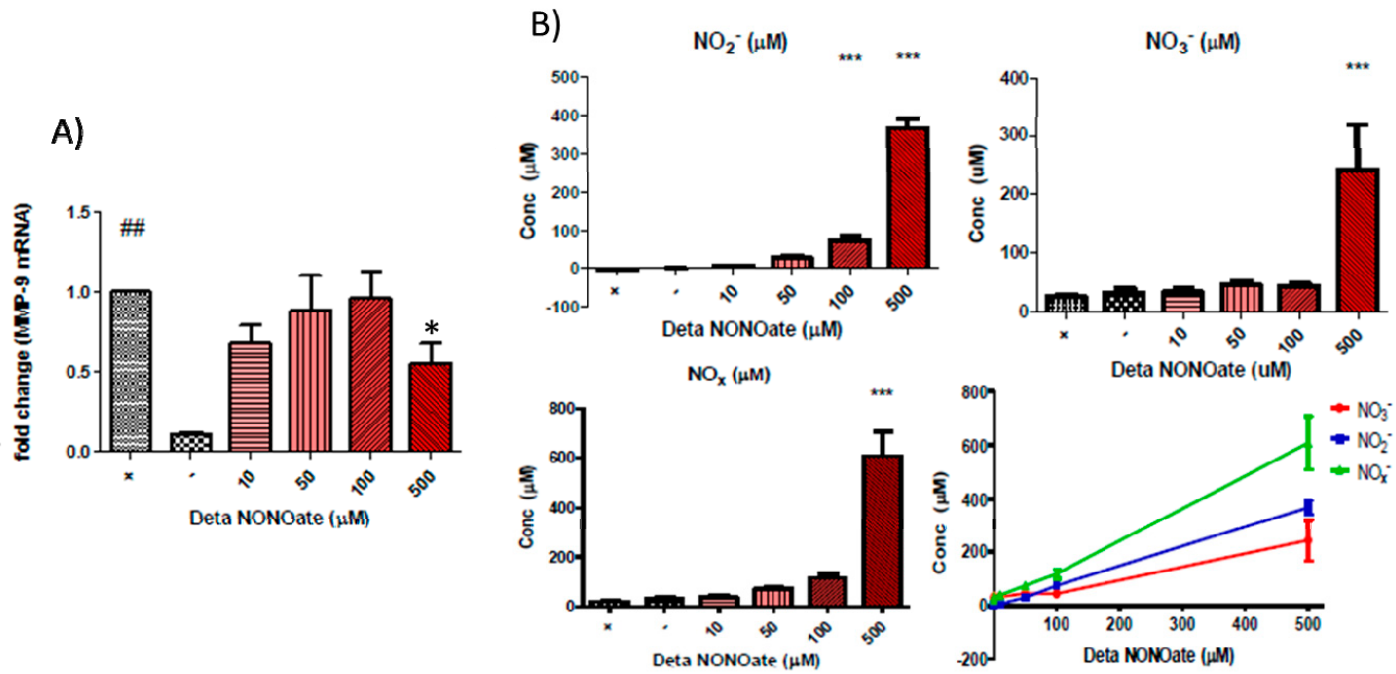

Figure 3. (A) DETA NONOate significantly reduced MMP-9 mRNA at high concentrations in cytokine-stimulated Caco-2 cells (\#\# $p<0.01$ vs. unstimulated Caco- 2 cells (negative control); ${ }^{*} p<0.05$ vs. cytokine-stimulated Caco-2 cells (positive control). (B) Measurements of nitrate and nitrite concentrations as breakdown products of NO by the Griess assay on the conditioned media of Caco- 2 cells after $24 \mathrm{~h}$ of co-incubation with DETA-NONOate and pro-inflammatory cytokines TNF- $\alpha$ and IL- $1 \beta$. Top left pane shows the nitrite concentration, top right panel shows the nitrate concentration, bottom left pane shows the combined reduced NO groups and bottom right shows the linear correlations of DETA-NONOate concentrations versus the concentration of measured $\mathrm{NOx}^{-}$species ( ${ }^{* *} p<0.001$ vs. negative control).

A)

B)
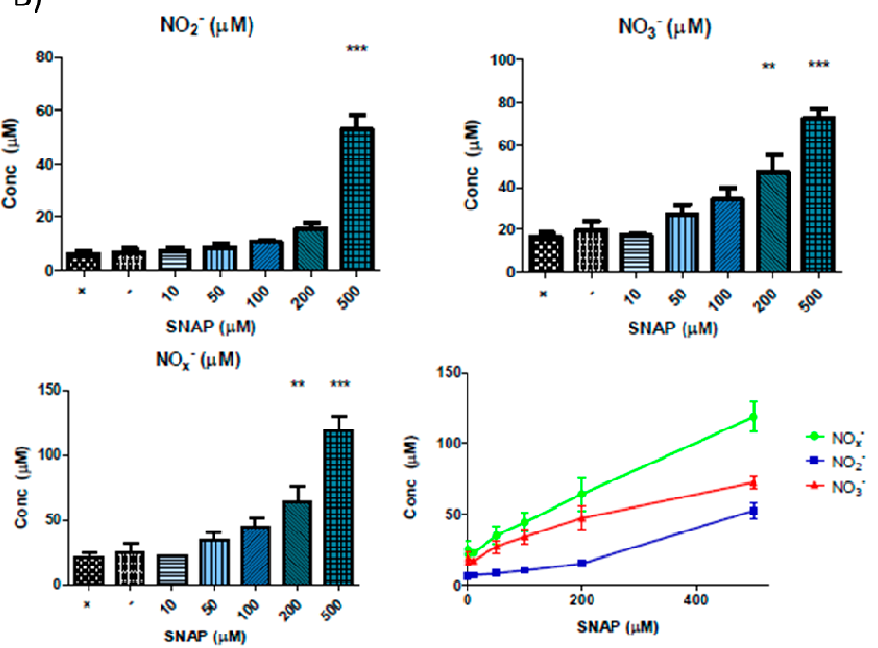

Figure 4. (A) SNAP significantly reduced MMP-9 mRNA at different concentrations tested in cytokine-stimulated Caco-2 cells: \#\# $p<0.01$ vs. unstimulated Caco-2 cells (negative control); ** $p<0.01$ vs. cytokine-stimulated Caco-2 cells (positive control). (B) Measurements of nitrate and nitrite concentrations as breakdown products of NO by the Griess assay on the conditioned media of Caco- 2 cells after $24 \mathrm{~h}$ of co-incubation with SNAP and proinflammatory cytokines TNF- $\alpha$ and IL-1 $\beta$. Top left pane shows the nitrite concentration, top right pane shows the nitrate concentration, bottom left pane shows the combined reduced NO groups and bottom right shows the linear correlations of SNAP concentrations versus the concentration of measured $\mathrm{NOx}^{-}$species. $\left({ }^{* *} p<0.01 \mathrm{vs}\right.$. negative control; ${ }^{* * *} p<0.001$ vs. negative control). 


\subsection{Barbiturate-Nitrate-Hybrids Inhibit MMP-9 Gene Expression in an NF- $\kappa B-I n d e p e n d e n t$ Manner}

In this study, we examined the effect of the barbiturate-nitrate hybrids on gene expression of various components of the NF- $\mathrm{kB}$ pathway and the nuclear binding of the p65 subunit to test the hypothesis that the compounds could mimic the effect of NO on NF- $\mathrm{kB}$.

A trend towards inhibition was observed for the nitrate-barbiturates that did not reach statistical significance (Figure 5A). Therefore, we decided to examine the effect of the compounds on the transcription of some of the elements of the NF- $\mathrm{kB}$ pathway.

The expression of RelA/p65, NF-kB1/p105 and IкBKG/NEMO, which forms part of the IKK complex, were assessed by qPCR (Figure 5B-D). However, the compounds showed a limited effect on RelA/p65, NF-kB1/p105 and IкBKG/NEMO with $\mathbf{1 a}, \mathbf{1 b}$ and $1 \mathrm{c}$ causing the greatest reduction in expression of these elements.

A)

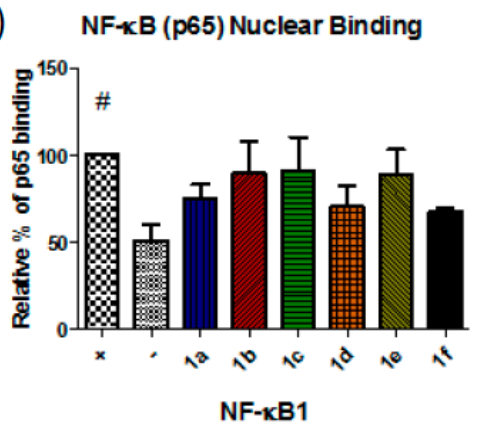

C)

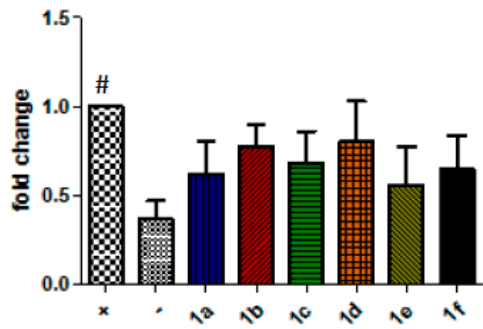

B)

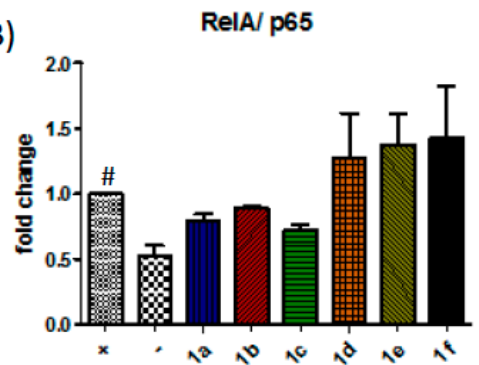

D)

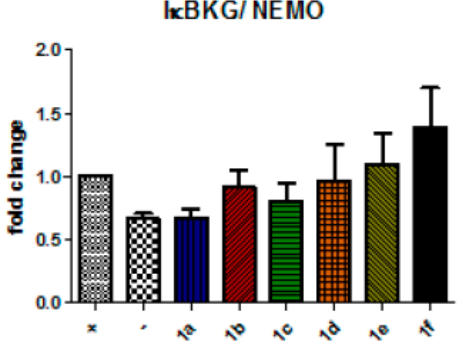

Figure 5. The barbiturate-nitrate hybrids show little effect on the NF- $\mathrm{KB}$ pathway. The nuclear translocation and binding of the NF- $\mathrm{KB}$ subunit $\mathrm{p} 65$ was measured using ELISA (A) and the gene expression of RelA/p65, NF-kB1/p105 and a component of the IKK complex, IkBG/NEMO were measured using qPCR (B-D). $\# p<0.05$ vs. unstimulated Caco-2 cells (negative control).

\subsection{Inhibition of MMP-9 by the Barbiturate-Nitrate Hybrids Is Partly Mediated Through a sGC/cGMP} Pathway

Following the limited effect of the compounds in altering NF- $\mathrm{kB}$ nuclear binding or expression of components of the pathway, we focused on the role of the cGMP pathway in mediating the inhibition of MMP-9 by the nitrate-barbiturates. This was first achieved using the pharmacological inhibitor $1 \mathrm{H}-(1,2,4)$ oxadiazolo(4,3-a)quinoxalin-1-one (ODQ), which is a highly selective and irreversible heme site inhibitor of sGC and is competitive with NO [21,22]. As shown in Figure 6A, co-incubation of the nitrate-barbiturates with ODQ abolished any reduction in MMP-9 gene expression, an effect which was reversed by adding the cGMP analogue 8-Br-cGMP to the cells (Figure 6B). These effects correlated with MMP-9 protein activity as shown in Figure 6C,D. 
A)

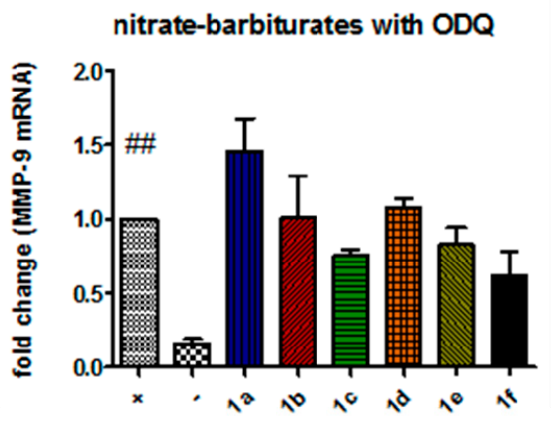

B)

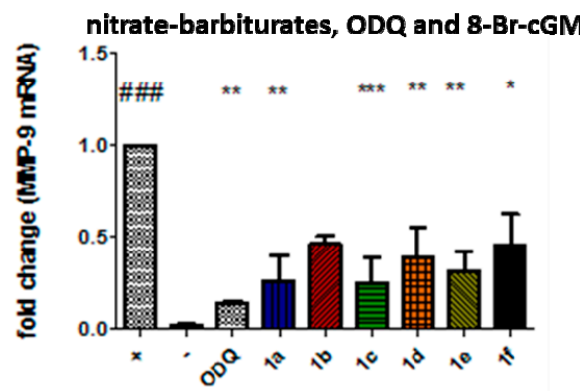

\section{Pro-MMP-9 (Zymography)}

C)

nitrate-barbiturates and $O D Q$

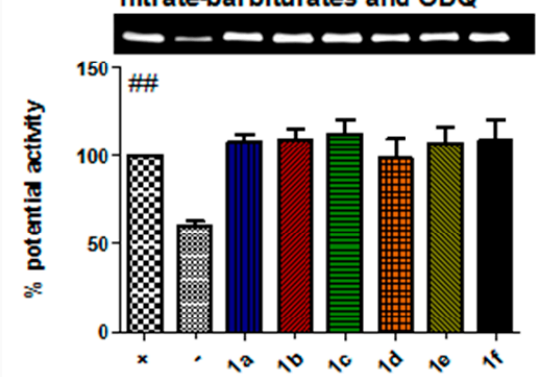

D)

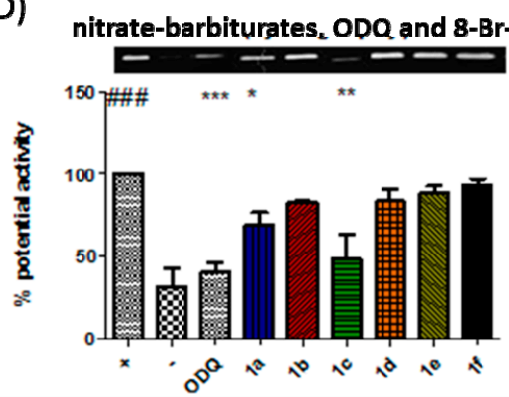

Figure 6. Barbiturate-nitrate hybrids inhibit MMP-9 via a soluble guanylate-cyclase-dependent pathway. (A) there was a significant up-regulation of the MMP-9 gene when inducing Caco-2 cells with the pro-inflammatory cytokines. When cells were activated in the presence of ODQ $(0.05 \mu \mathrm{M})$, this resulted in a reversion of MMP-9 mRNA levels in barbiturate-nitrate hybrid-treated cells. (B) Exogenously added 8-bromo-cGMP restored the effect of ODQ $(0.5 \mu \mathrm{M})$. These results correlated with the pro-MMP-9 protein activity as shown by zymography $(\mathbf{C}, \mathbf{D}) \# \# p<0.01$ vs. unstimulated Caco- 2 cells (negative control); \#\#\# $p<0.001$ vs. negative control; ${ }^{*} p<0.05$ vs. cytokine-stimulated Caco- 2 cells (positive control); ${ }^{* *} p<0.01$ vs. positive control; ${ }^{* *} p<0.001$ vs. positive control.

\section{Discussion}

Understanding that MMP-9 remains an attractive target for inhibition in a variety of inflammatory conditions, our group designed a series of barbiturate-based hybrids that are intrinsically active as MMP inhibitors at the enzyme level but have additional effects on MMP activity through a nitrate moiety [17]. The present findings indicate that the hybrid compounds, which inhibit at the enzyme level, also reduce MMP-9 at the gene level in response to inflammatory stimuli. These effects are mediated by NO mimicry in cGMP activation and they are selective for MMP-9 inhibition over MMP-1 and MMP-2.

MMPIs have failed in clinical trials due to disappointing clinical efficacy results compared to animal trials and dose-limiting side-effects of MSS; but we can now reflect on how little was known of the complex protease network or the net effect of inhibition of certain enzymes in a given setting. The trials added MMPIs as co-therapies for patients with invasive or metastatic cancer, which may not have been appropriate considering that metastasis was already established and also, the genetic diversity of the disease [13]. It is now known that the MMPs may play a protective role in tumour progression $[23,24]$ including MMP-8 and indeed much broader roles in inflammation than previously appreciated, many of which are protective $[25,26]$. Setting will be crucial to the success of MMPIs, and so as we understand more about the interactions of the MMP network and the roles of individual MMPs in a given disease setting, we may be better able to appropriately target them for inhibition. While broad spectrum inhibition may be appropriate in certain acute inflammatory settings, selectivity may be important in reducing side-effects in chronic inflammatory conditions. With the difficulties in finding selective and clinically useful active-site inhibitors, alternative strategies such as blocking upstream 
pathways of activation $[27,28]$ or indeed targeting the transcriptional upregulation of the enzyme is of utmost importance. Xanthine-derivatives, NSAIDs and 3-hydroxy-3-methylglutaryl coenzyme A (HMG-CoA) reductase inhibitors have all been studied as inhibitors of MMP-9 expression [9]. Doxycycline, the only clinically approved drug acting through MMP inhibition [29], is a weak enzyme level inhibitor [30] which exerts its effects mainly at the transcriptional level [31-33].

In previous studies, we established that the hybrid compounds affect MMP-9 secretion [17], but it was unclear if this was at the storage, secretory or transcriptional level. In this study, we found a profound reduction of MMP-9 mRNA with the hybrid compounds on cytokine-stimulated cells. These effects were not observed on MMP-1 and MMP- 2 mRNA. We also found a smaller but significant reduction in MMP-9 transcription with the alcohol-barbiturates. The inhibitory effect of the non-nitrates on MMP transcription is probably due to a general anti-inflammatory effect associated with MMP-9 inhibition at enzyme level. The MMPs catalyse the activation of a broad range of substrates [2,34], which can promote the transcriptional up-regulation of pro-inflammatory mediators, including MMPs themselves. MMPs have become common read-outs for inflammation in cell and animal models of IBD. For example, in a rat model of UC, the broad spectrum hydroxamate MMP inhibitor, ilomastat, was shown to inhibit MMP-1 expression in the colon [35]. The nitrate side-chains tested alone also reduced MMP-9 levels with a similar order of magnitude to the alcohol-barbiturates. The striking effect of the hybrid compounds on MMP-9 expression may be attributed to an indirect inhibitory action at the enzyme level and an additional NO-mediated effect at the mRNA level.

Next, we tested the effects of NO-donors on MMP-9 in our model of intestinal epithelial inflammation in order to ascribe some of the MMP-9 inhibitory action of the compounds to the nitrate moiety. In our experiments, SNAP and DETA-NONOate were chosen as NO-donors to represent varying NO release profiles. There was a linear relationship between the concentration of the compound used and the concentration of nitrate and nitrite, breakdown products of NO, that were in the media after $24 \mathrm{~h}$. Cytokine-stimulated cells that were incubated with SNAP showed a large inhibition of MMP-9 gene expression. DETA-NONOate was used in the same range of concentrations as SNAP but did not result in the same effect on MMP-9. It is interesting to note that while there was a direct correlation between the concentration of donor used and the $\mathrm{NO}_{\mathrm{x}}{ }^{-}$species measured, this did not correlate with the effect on MMP-9 despite both NO-donors having some inhibitory effect. The half-life of $\mathrm{NO}$ in a biological setting is in the range of seconds and so the measurement of its breakdown products after $24 \mathrm{~h}$ may not necessarily be relevant. SNAP is expected to breakdown spontaneously and has a shorter half-life than DETA-NONOate and will likely produce a higher concentration of NO that may be sustained for a shorter period of time and it may be this property that resulted in the inhibition of MMP-9 mRNA.

Knowing that the nitrate-barbiturates can inhibit MMP-9 transcription, that NF- $\mathrm{kB}$ is involved in the upregulation of MMP-9 and that NF- $\mathrm{KB}$ is sensitive to NO, we decided to assess the effect of the compounds on the NF- $\mathrm{KB}$ pathway. NF- $\mathrm{KB}$ exists in the cytoplasm as an inactive dimer bound to its inhibitor IкB. Activation of the IKK complex liberates the dimer to migrate to the nucleus and interact with $\mathrm{\kappa B}$ binding sites in the promoter regions of certain genes. The MMP-9 gene contains at least two of these binding sites in its promoter region [36] and NF-KB has been shown to be essential for MMP-9 upregulation [37-39]. NF- $\kappa B$ can induce the expression of iNOS when activated and NO is a known regulator of NF- $\mathrm{kB}$, likely functioning in a concentration-dependent negative feedback loop $[40,41]$. We have previously reviewed the evidence for the NO's modulation of NF-kB in the context of MMP-9 [18]. Therefore, we decided to assess the effect of the compounds on the NF- $k B$ pathway. An ELISA of the p65 subunit was used to measure the nuclear binding of the NF- $\mathrm{kB}$ complex. There was a trend of inhibition for all the compounds with a maximum mean reduction of $32 \%$, but the observed reductions were not statistically significant. To further investigate the effect on p65 nuclear binding, we measured the effect of the compounds on the expression of some of the components of the NF- $\mathrm{kB}$ pathway. RelA and NF- $\mathrm{kB} 1$ are common components of the NF- $\mathrm{kB}$ complex, a protein dimer that will bind to its response element on certain genes. Although the primary mechanism of 
regulation is its liberation from IKB, it is still under transcriptional control and these two components are both upregulated by pro-inflammatory cytokines in Caco-2 cells. IKBKG is part of the IKK complex, which can phosphorylate I $\kappa B$, leaving the NF- $k B$ complex free to migrate to the nucleus. The difference between the sham and stimulated controls was small, which reflects the fact that transcriptional control is not the primary mechanism of regulation of IKBKG. The compounds exerted a limited effect on RelA/p65, NF-kB1/p105 and IкBKG/NEMO.

We next turned our attention to cGMP as a candidate for the NO-mediated effect. The cGMP pathway is one of the most well-defined ways that NO exerts many of its effects such as vasodilation and inhibition of platelet aggregation. NO can react with the heme centre of sGC, increasing the rate of catalytic conversion of GTP to cGMP [42]. sGC can mediate the transcriptional upregulation of COX-2, TNF, plasminogen activator inhibitor-1 (PAI-1), vascular endothelial growth factor receptor-1 (VEGFR1), mitogen-activated protein kinase phosphatase-1 (MKP-1) and MMP-9. The exact mechanism by which cGMP exerts its transcription regulatory functions has not been fully explained but it can alter the function of cGMP-regulated ion channels, cGMP-regulated phosphodiesterases and cGMP-dependent protein kinases (PKG) [43]. Several lines of evidence suggest PKG as the mediator of sGC action on MMP-9 gene transcription [44-47]. Co-incubation of the hybrid compounds with the sGC inhibitor ODQ, abolished their MMP-9 inhibitory effects and no differences were observed between the compound treated cells and the positive control at the level of gene transcription or enzyme activity. We could therefore deduce that the nitrate-barbiturates inhibited MMP-9 transcription in a sGC-dependent manner. To confirm this result and further elucidate the pathway, the cGMP analogue, 8-Br-cGMP, was added with the compounds along with ODQ, and it was found that the inhibitory properties of the compounds were restored to what they were with the compounds alone. We can therefore conclude that nitrate-barbiturates exert their inhibitory action on MMP-9 transcription through a sGC-cGMP pathway.

In summary, both control NO donors were able to exert some inhibitory effect on MMP-9 transcription in cytokine-stimulated Caco-2 cells, but this effect was independent of the $\mathrm{NO}^{-}{ }^{-}$ concentration after $24 \mathrm{~h}$. The barbiturate-nitrate hybrids, which are established enzyme level inhibitors, also inhibit MMP-9 at the gene level, an effect that is partly mediated by the nitrate group through a sGC-cGMP pathway. This discovery highlights the potential of these drugs in treating colonic inflammation and also represents a novel mechanism for correcting MMP dysregulation in inflammatory diseases. New studies are guaranteed to test these new compounds in other inflammatory conditions where MMP-9 upregulation plays an important role.

Author Contributions: S.O., J.W., M.W.R., J.F.G. and C.M. have contributed to the design of the work; acquisition, analysis and interpretation of data; drafting the work; final approval of the version; and agreement to be accountable for all aspects of the work. All authors have read and agreed to the published version of the manuscript.

Funding: This work was supported by Science Foundation Ireland (SFI-RFP/BMT2781) awarded to C.M. and J.F.G.

Conflicts of Interest: The authors declare no conflict of interest.

\section{References}

1. Vandooren, J.; Steen, P.E.V.D.; Opdenakker, G. Biochemistry and molecular biology of gelatinase B or matrix metalloproteinase-9 (MMP-9): The next decade. Crit. Rev. Biochem. Mol. Biol. 2013, 48, 222-272. [CrossRef] [PubMed]

2. Rodríguez, D.; Morrison, C.J.; Overall, C.M. Matrix metalloproteinases: What do they not do? New substrates and biological roles identified by murine models and proteomics. Biochim. Biophys. Acta 2010, 1803, 39-54. [CrossRef] [PubMed]

3. Mehana, E.-S.E.; Khafaga, A.F.; El-Blehi, S.S.; El-Sayed, M.E.; Khafaga, A.F.; Samar, E.-B.S. The role of matrix metalloproteinases in osteoarthritis pathogenesis: An updated review. Life Sci. 2019, 234, 116786. [CrossRef] [PubMed] 
4. Medina, C.; Videla, S.; Radomski, A.; Radomski, M.W.; Antolín, M.; Guarner, F.; Vilaseca, J.; Salas, A.; Malagelada, J.-R. Increased activity and expression of matrix metalloproteinase-9 in a rat model of distal colitis. Am. J. Physiol. Liver Physiol. 2003, 284, G116-G122. [CrossRef]

5. Medina, C.; Santana, A.; Paz, M.C.; Díaz-González, F.; Farre, E.; Salas, A.; Radomski, M.W.; Quintero, E. Matrix metalloproteinase-9 modulates intestinal injury in rats with transmural colitis. J. Leukoc. Biol. 2006, 79, 954-962. [CrossRef]

6. Castaneda, F.E.; Walia, B.; Vijay-Kumar, M.; Patel, N.R.; Roser, S.; Kolachala, V.L.; Rojas, M.; Wang, L.; Oprea, G.; Garg, P.; et al. Targeted Deletion of Metalloproteinase 9 Attenuates Experimental Colitis in Mice: Central Role of Epithelial-Derived MMP. Gastroenterology 2005, 129, 1991-2008. [CrossRef]

7. Al-Sadi, R.; Youssef, M.; Rawat, M.; Guo, S.; Dokladny, K.; Haque, M.; Watterson, M.D.; Ma, T.Y.; Watterson, D.M. MMP-9-induced increase in intestinal epithelial tight permeability is mediated by p38 kinase signaling pathway activation of MLCK gene. Am. J. Physiol. Liver Physiol. 2019, 316, G278-G290. [CrossRef]

8. Opdenakker, G.; Steen, P.E.V.D.; Van Damme, J. Gelatinase B: A tuner and amplifier of immune functions. Trends Immunol. 2001, 22, 571-579. [CrossRef]

9. Atkinson, J.J.; Senior, R.M. Matrix Metalloproteinase-9 in Lung Remodeling. Am. J. Respir. Cell Mol. Biol. 2003, 28, 12-24. [CrossRef]

10. Mohan, R.; Chintala, S.K.; Jung, J.-C.; Villar, W.V.L.; McCabe, F.; Russo, L.A.; Lee, Y.; McCarthy, B.E.; Wollenberg, K.R.; Jester, J.V.; et al. Matrix Metalloproteinase Gelatinase B (MMP-9) Coordinates and Effects Epithelial Regeneration. J. Biol. Chem. 2001, 277, 2065-2072. [CrossRef]

11. Fini, M.E.; Parks, W.C.; Rinehart, W.B.; Girard, M.T.; Matsubara, M.; Cook, J.R.; West-Mays, J.A.; Sadow, P.M.; Burgeson, R.E.; Jeffrey, J.J.; et al. Role of matrix metalloproteinases in failure to re-epithelialize after corneal injury. Am. J. Pathol. 1996, 149, 1287-1302. [PubMed]

12. Hu, J.; Steen, P.E.V.D.; Sang, Q.-X.A.; Opdenakker, G. Matrix metalloproteinase inhibitors as therapy for inflammatory and vascular diseases. Nat. Rev. Drug Discov. 2007, 6, 480-498. [CrossRef] [PubMed]

13. Winer, A.; Adams, S.; Mignatti, P. Matrix Metalloproteinase Inhibitors in Cancer Therapy: Turning Past Failures Into Future Successes. Mol. Cancer Ther. 2018, 17, 1147-1155. [CrossRef] [PubMed]

14. Grams, F.; Brandstetter, H.; Dalò, S.; Geppert, D.; Krell, H.-W.; Leinert, H.; Livi, V.; Menta, E.; Oliva, A.; Zimmermann, G. Pyrimidine-2,4,6-Triones: A New Effective and Selective Class of Matrix Metalloproteinase Inhibitors. Biol. Chem. 2001, 382, 1277-1285. [CrossRef] [PubMed]

15. Breyholz, H.-J.; Schäfers, M.; Wagner, S.; Höltke, C.; Faust, A.; Rabeneck, H.; Levkau, B.; Schober, O.; Kopka, K. C-5-Disubstituted Barbiturates as Potential Molecular Probes for Noninvasive Matrix Metalloproteinase Imaging. J. Med. Chem. 2005, 48, 3400-3409. [CrossRef] [PubMed]

16. Foley, L.H.; Palermo, R.; Dunten, P.; Wang, P. Novel 5,5-disubstitutedpyrimidine-2,4,6-triones as selective MMP inhibitors. Bioorganic Med. Chem. Lett. 2001, 11, 969-972. [CrossRef]

17. Wang, J.; O'Sullivan, S.; Harmon, S.; Keaveny, R.; Radomski, M.W.; Medina, C.; Gilmer, J.F. Design of Barbiturate-Nitrate Hybrids that Inhibit MMP-9 Activity and Secretion. J. Med. Chem. 2012, 55, 2154-2162. [CrossRef]

18. O'Sullivan, S.; Medina, C.; Ledwidge, M.; Radomski, M.W.; Gilmer, J.F. Nitric oxide-matrix metaloproteinase-9 interactions: Biological and pharmacological significance. Biochim. Biophys. Acta 2014, 1843, 603-617. [CrossRef]

19. O'Sullivan, S.; Wang, J.; Pigott, M.T.; Docherty, N.; Boyle, N.; Lis, S.K.; Gilmer, J.F.; Medina, C. Inhibition of matrix metalloproteinase- 9 by a barbiturate-nitrate hybrid ameliorates dextran sulphate sodium-induced colitis: Effect on inflammation-related genes. Br. J. Pharmacol. 2017, 174, 512-524. [CrossRef]

20. Webb, D.J.; Megson, I. Nitric oxide donor drugs: Current status and future trends. Expert Opin. Investig. Drugs 2002, 11, 587-601. [CrossRef]

21. Schrammel, A.; Behrends, S.; Schmidt, K.; Koesling, D.; Mayer, B. Characterization of $1 \mathrm{H}-(1,2,4)$ oxadiazolo(4,3-a)quinoxalin-1-one as a heme-site inhibitor of nitric oxide-sensitive guanylyl cyclase. Mol. Pharmacol. 1996, 50, 1-5. [PubMed]

22. Garthwaite, J.; Southam, E.; Boulton, C.L.; Nielsen, E.B.; Schmidt, K.; Mayer, B. Potent and selective inhibition of nitric oxide-sensitive guanylyl cyclase by $1 \mathrm{H}-(1,2,4)$ oxadiazolo(4,3-a)quinoxalin-1-one. Mol. Pharmacol. 1995, 48, 184-188. [PubMed]

23. Martin, M.D.; Matrisian, L.M. The other side of MMPs: Protective roles in tumor progression. Cancer Metastasis Rev. 2007, 26, 717-724. [CrossRef] [PubMed] 
24. Juurikka, K.; Butler, G.S.; Salo, T.; Nyberg, P.; Åström, P. The Role of MMP8 in Cancer: A Systematic Review. Int. J. Mol. Sci. 2019, 20, 4506. [CrossRef] [PubMed]

25. Dufour, A.; Overall, C.M. Missing the target: Matrix metalloproteinase antitargets in inflammation and cancer. Trends Pharmacol. Sci. 2013, 34, 233-242. [CrossRef] [PubMed]

26. Takahashi, Y.; Kobayashi, T.; D’Alessandro-Gabazza, C.N.; Toda, M.; Fujiwara, K.; Okano, T.; Fujimoto, H.; Asayama, K.; Takeshita, A.; Yasuma, T.; et al. Protective Role of Matrix Metalloproteinase-2 in Allergic Bronchial Asthma. Front. Immunol. 2019, 10, 1795. [CrossRef]

27. Gong, Y.; Hart, E.; Shchurin, A.; Hoover-Plow, J. Inflammatory macrophage migration requires MMP-9 activation by plasminogen in mice. J. Clin. Investig. 2008, 118, 3012-3024. [CrossRef]

28. Fayard, B.; Bianchi, F.; Dey, J.; Moreno, E.; Djaffer, S.; E Hynes, N.; Monard, D. The Serine Protease Inhibitor Protease Nexin-1 Controls Mammary Cancer Metastasis through LRP-1-Mediated MMP-9 Expression. Cancer Res. 2009, 69, 5690-5698. [CrossRef]

29. Dormán, G.; Kocsis-Szommer, K.; Spadoni, C.; Ferdinandy, P. MMP Inhibitors in Cardiac Diseases: An Update. Recent Patents Cardiovasc. Drug Discov. 2007, 2, 186-194. [CrossRef]

30. Garcia, R.A.; Pantazatos, D.P.; Gessner, C.R.; Go, K.V.; Woods, V.L.; Villarreal, F.J. Molecular Interactions between Matrilysin and the Matrix Metalloproteinase Inhibitor Doxycycline Investigated by Deuterium Exchange Mass Spectrometry. Mol. Pharmacol. 2005, 67, 1128-1136. [CrossRef]

31. Egeblad, M.; Werb, Z. New functions for the matrix metalloproteinases in cancer progression. Nat. Rev. Cancer 2002, 2, 161-174. [CrossRef] [PubMed]

32. Ramamurthy, N.S.; Rifkin, B.R.; Greenwald, R.A.; Xu, J.-W.; Liu, Y.; Turner, G.; Golub, L.M.; Vernillo, A. Inhibition of Matrix Metalloproteinase-Mediated Periodontal Bone Loss in Rats: A Comparison of 6 Chemically Modified Tetracyclines. J. Periodontol. 2002, 73, 726-734. [CrossRef] [PubMed]

33. Paemen, L.; Martens, E.; Norga, K.; Masure, S.; Roets, E.; Hoogmartens, J.; Opdenakker, G. The gelatinase inhibitory activity of tetracyclines and chemically modified tetracycline analogues as measured by a novel microtiter assay for inhibitors. Biochem. Pharmacol. 1996, 52, 105-111. [CrossRef]

34. Sternlicht, M.D.; Werb, Z. How Matrix Metalloproteinases Regulate Cell Behavior. Annu. Rev. Cell Dev. Biol. 2001, 17, 463-516. [CrossRef] [PubMed]

35. Wang, Y.-D.; Wang, W. Protective effect of ilomastat on trinitrobenzenesulfonic acid-induced ulcerative colitis in rats. World J. Gastroenterol. 2008, 14, 5683-5688. [CrossRef] [PubMed]

36. St-Pierre, Y.; Couillard, J.; Van Themsche, C. Regulation of MMP-9 gene expression for the development of novel molecular targets against cancer and inflammatory diseases. Expert Opin. Ther. Targets 2004, 8, 473-489. [CrossRef]

37. Eberhardt, W.; Huwiler, A.; Beck, K.F.; Walpen, S.; Pfeilschifter, J. Amplification of IL-1 beta-induced matrix metalloproteinase- 9 expression by superoxide in rat glomerular mesangial cells is mediated by increased activities of NF-kappa B and activating protein-1 and involves activation of the mitogen-activated protein kinase pathways. J. Immunol. 2000, 165, 5788-5797.

38. Bond, M.; Fabunmi, R.P.; Baker, A.H.; Newby, A. Synergistic upregulation of metalloproteinase-9 by growth factors and inflammatory cytokines: An absolute requirement for transcription factor NF-kappa B. FEBS Lett. 1998, 435, 435. [CrossRef]

39. Bond, M.; Chase, A.J.; Baker, A.H.; Newby, A. Inhibition of transcription factor NF-kappaB reduces matrix metalloproteinase-1, -3 and -9 production by vascular smooth muscle cells. Cardiovasc. Res. 2001, 50, 556-565. [CrossRef]

40. Chen, X.; Chang, L.; Li, X.; Huang, J.; Yang, L.; Lai, X.; Huang, Z.; Wang, Z.; Wu, X.; Zhao, J.; et al. Tc17/IL-17A Up-Regulated the Expression of MMP-9 via NF-кB Pathway in Nasal Epithelial Cells of Patients with Chronic Rhinosinusitis. Front. Immunol. 2018, 9, 2121. [CrossRef]

41. Janssen-Heininger, Y.M.W.; E Poynter, M.; A Baeuerle, P. Recent advances towards understanding redox mechanisms in the activation of nuclear factor kappaB. Free. Radic. Biol. Med. 2000, 28, 1317-1327. [CrossRef]

42. Dijkstra, G.; Moshage, H.; Jansen, P.L.M. Blockade of NF-k B Activation and Donation of Nitric Oxide: New Treatment Options in Inflammatory Bowel Disease? Scand. J. Gastroenterol. 2002, 37, 37-41. [CrossRef] [PubMed]

43. Pfeilschifter, J.; Eberhardt, W.; Beck, K.-F. Regulation of gene expression by nitric oxide. Pflüger 2001, 442, 479-486. [CrossRef] [PubMed] 
44. Ahern, G. cGMP and S-nitrosylation: Two routes for modulation of neuronal excitability by NO. Trends Neurosci. 2002, 25, 510-517. [CrossRef]

45. Gudi, T.; Hong, G.K.-P.; Vaandrager, A.B.; Lohmann, S.M.; Pilz, R.B. Nitric oxide and cGMP regulate gene expression in neuronal and glial cells by activating type II cGMP-dependent protein kinase. FASEB J. 1999, 13, 2143-2152. [CrossRef] [PubMed]

46. Huvar, I. Regulation of Gene Expression by cGMP-dependent Protein Kinase. J. Biol. Chem. 1996, 271, 4597-4600. [CrossRef]

47. Gudi, T.; Lohmann, S.M.; Pilz, R.B. Regulation of gene expression by cyclic GMP-dependent protein kinase requires nuclear translocation of the kinase: Identification of a nuclear localization signal. Mol. Cell. Biol. 1997, 17, 5244-5254. [CrossRef]

(C) 2020 by the authors. Licensee MDPI, Basel, Switzerland. This article is an open access article distributed under the terms and conditions of the Creative Commons Attribution (CC BY) license (http://creativecommons.org/licenses/by/4.0/). 